\title{
A One Hundred Year Review-Foreign Expert Professor Groff at the Agricultural College of Lingnan University
}

\author{
Mu-chan LIN, Yuan CHEN and Hui-li WU \\ South China Agricultural University, Guangzhou, China 510642
}

Keywords: Lingnan University, Agricultural, Foreign Expert, Review.

\begin{abstract}
This article reviews the early development of Lingnan University, a private university established in Guangzhou over 100 years ago, it introduces the achievement of the main contributor professor Groff using numerous historical pictures showing the early development of the agriculture college of Lingnan University. The contribution of Professor Groff in campus planning, promoting the development of plantation and breeding, promoting aquaculture development and food processing is highly recognized, as well as in the development of discipline and academic exchange in Lingnan University.
\end{abstract}

\section{Introduction}

On November 19, 2015, the Governor of Guangdong recruited ten new "foreign advisers", including world-class entrepreneurs, economists, and education experts, to solicit their advice and suggestions regarding innovation and development within Guangdong's economy. Ten groups of experts have been recruited since 1999.

Remarkably, traces of these foreign experts and their achievements can be found throughout the full history of the College of Agriculture at Lingnan University, one of the predecessors of South China Agricultural University. One hundred years ago, these foreign experts travelled a formidable distance to China to teach at Lingnan University; the best among them includes Prof. George Weidmen Groff, who taught at Lingnan for 36 years and made very notable contributions to the university's development.

\section{Preface}

In the late 19th century, alongside rapid and dramatic development within Chinese society, China's education system transformed from traditional private schools to modern public schools. Traditionally, schools focused on ensuring success on imperial examinations; modern schools emphasize natural sciences and practical knowledge. At this time, many such new schools appeared in China that were founded and funded by Western churches, and some gradually transformed to Christian universities. Lingnan University is an excellent example. In 1927, the management of the university passed into Chinese hands, at which time it became the first private university managed by solely Chinese educators.

\section{Lingnan University and Early Agricultural Development}

Lingnan University originated from Christian College of China in 1888, which was set up in Aki Kinley Port by Doctor A. P. Happer as an agent of the Presbyterian Church of Christ. In 1893, the college broke away from the Church with its own Trustees of the Christian College in China to become a university of Christ with no relation to the Western church. The college moved to Macao in 1900 and changed its name again to 
Canton Christian College, (or the Lingnan School,) in 1903. In 1904, the school was expanded onto 30 acres of land purchased from Kangle Village, Guangzhou, so as to establish a central campus which is now the southern campus of Sun Yat-Sen University.

Canton Christian College was a pioneering educational institution characterized by scientific and advanced Western educational philosophy that broke through outdated pedagogical barriers. At the very beginning, most of its teachers came from other countries to teach such courses as English and Natural Sciences, which were strikingly innovative at the time. Martin Hall, the first permanent building, was finished in 1906 and followed quickly by 20 other buildings. At the end of spring and beginning of summer of 1907, George Weidmen Groff came to Guangzhou at 23 years old appointed by Pennsylvania State University and became a teacher at the college. During his following 36 years in Guangdong, he forged the development of modern higher education and modern agricultural sciences.
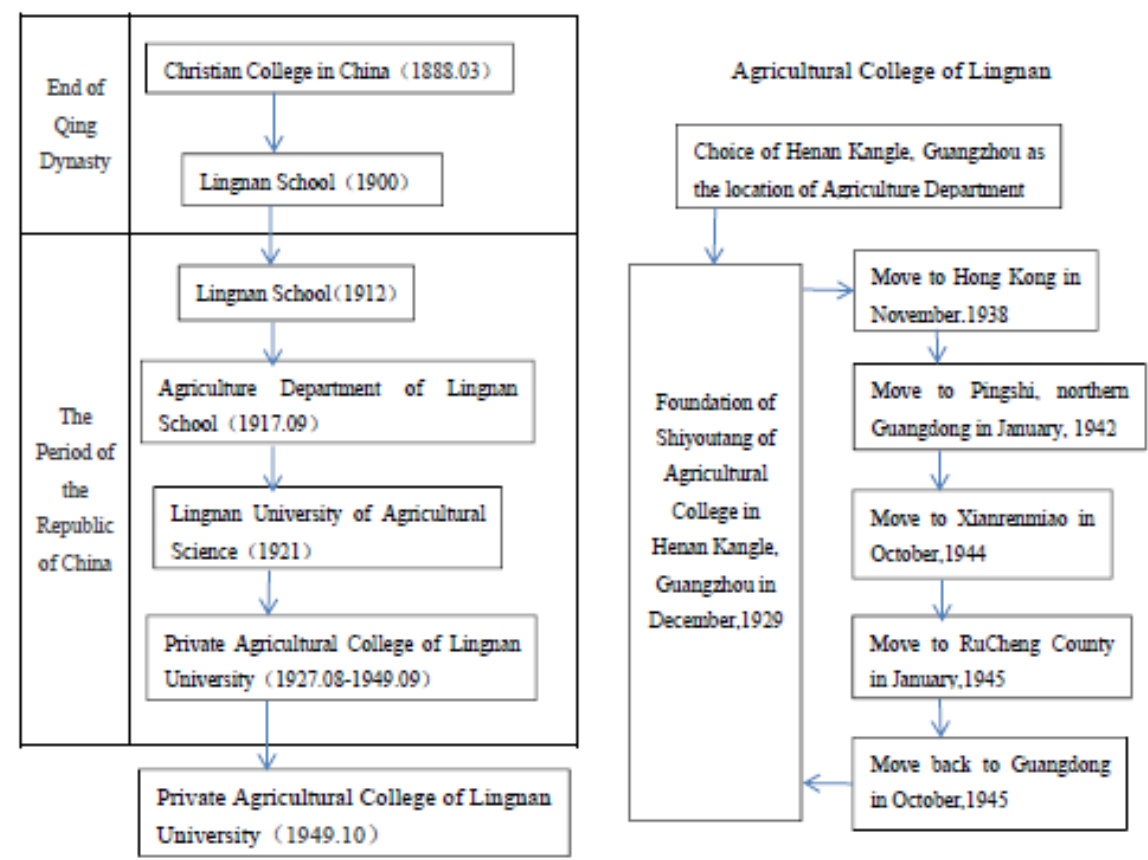

Historical Development of Private Agricultural College of Lingnan University and it's Various Locations During the Founding Period

Table 1. Leaders of Lingnan University of Agricultural Science and Agriculture Department of Lingnan University

\begin{tabular}{|c|c|c|c|}
\hline \multirow{2}{*}{$\begin{array}{c}\text { University Name } \\
\text { Changes }\end{array}$} & \multicolumn{2}{|c|}{ Leader } & \multirow{2}{*}{ In Office } \\
\hline & Post & Name & \\
\hline $\begin{array}{c}\text { Lingnan University of } \\
\text { Agricultural Science } \\
(1917-1921)\end{array}$ & $\begin{array}{l}\text { President } \\
\text { President }\end{array}$ & $\begin{array}{c}\text { George Weidmen Groff } \\
\text { Luo Feiyun }\end{array}$ & $\begin{array}{l}1917-1918 \\
1918-1921\end{array}$ \\
\hline $\begin{array}{c}\text { Agriculture } \\
\text { Department of } \\
\text { Lingnan University } \\
(1921-1927.8)\end{array}$ & $\begin{array}{l}\text { Dean } \\
\text { Dean }\end{array}$ & $\begin{array}{l}\text { Zhong Rongguang } \\
\text { George Weidmen Groff }\end{array}$ & $\begin{array}{l}1921-1922 \\
1922-1927\end{array}$ \\
\hline $\begin{array}{l}\text { Private Agricultural } \\
\text { College of Lingnan } \\
\text { University } \\
(1927.8-1952.10)\end{array}$ & $\begin{array}{c}\text { Dean } \\
\text { Dean } \\
\text { Associate Dean } \\
\text { Dean } \\
\text { Dean }\end{array}$ & $\begin{array}{c}\text { Zhang Chaokun } \\
\text { Feng Rui } \\
\text { Gu Guifen } \\
\text { Gu Guifen } \\
\text { Li Peiwen }\end{array}$ & $\begin{array}{c}1927.8-1928 \\
1928-1934 \\
1934-1935 \\
1935-1940.9 \\
1940.10-1952 \\
\end{array}$ \\
\hline
\end{tabular}




\section{Introduction to Professor Groff}

Professor George Weidmen Groff (1884-1954), an expert in Horticulture, undertook the foundation of Agricultural College of Lingnan University (later the South China Agricultural University) in 1899 accompanied by Mr. Zhong Rongguang, the academic dean of Lingnan School. After the four-year agricultural education program was set up in 1917, Groff served as the dean of Lingnan School of Agricultural Science from 1917 to 1918. Toward the end of 1918, the school changed into Lingnan University, a full set of university courses were developed, and the first three undergraduates graduated. Subsequent graduates were granted opportunities to study for postgraduate degrees in about 15 universities across the globe, including Harvard, Yale, Columbia, Stanford, and Toronto University.

After the Agricultural College of Lingnan University was established in 1921, Groff took up the post of dean for two terms between 1922 and 1927. The university restructured and changed into Private Lingnan University in 1927, and Groff, apart from a brief departure to the United States for the founding of the Plant Exchange Center, maintained a position at the university until his retirement in 1947. Groff indeed led most of his life and career at Lingnan University, and made extraordinary contributions to the foundation and development of the Agricultural College.

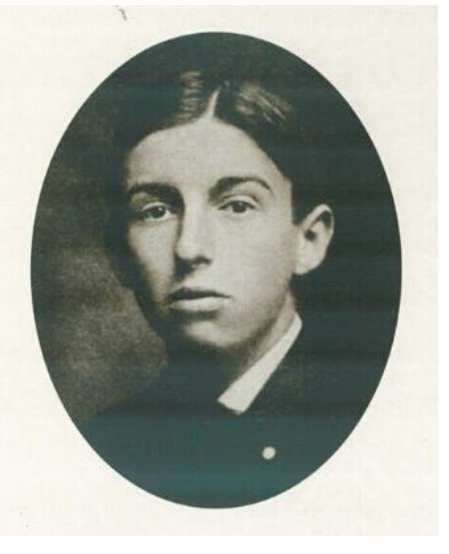

Figure 1. Groff as a young man.

In 1907, after the foundation of Lingnan School, Groff came to China as a volunteer from Pennsylvania State University and became the first American pioneer in agricultural education in the region.

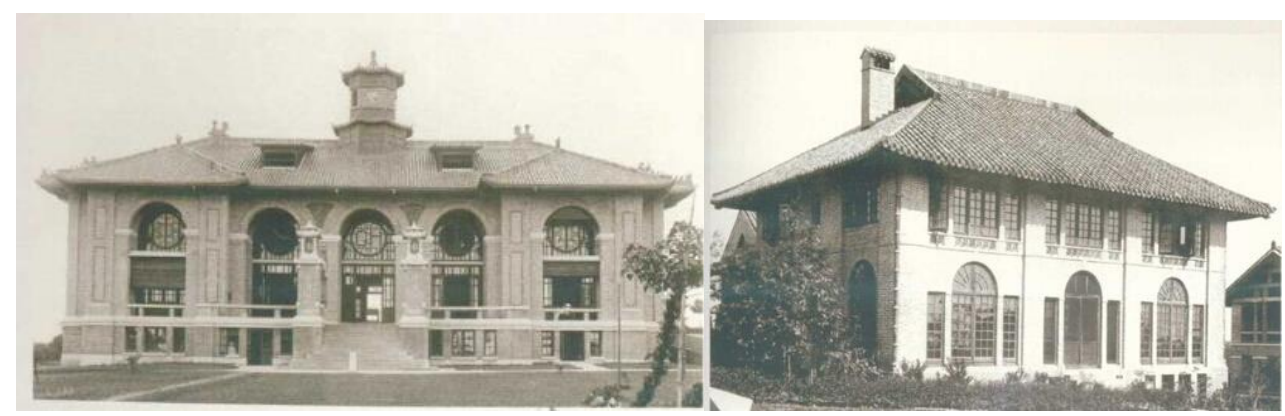

Figure 2. Grant Hall, in honor of Mr. Grant, also called Figure 3. Penn State Lodge.

"Big Bell Tower" was formerly the office of Lingnan University of Agricultural Science where Groff worked.

Figure 3 is an image of Groff's residence during his time as the dean of the Agricultural College. The building was constructed with donations in 1920 from 
teachers and students from Pennsylvania State University to honor his valuable contributions to the school, and Groff resided there from 1920 to 1941. It later was a residence for $\mathrm{Xu}$ Chongqing, and is now the Research Center for Historical Anthropology of Sun Yat-sen University.

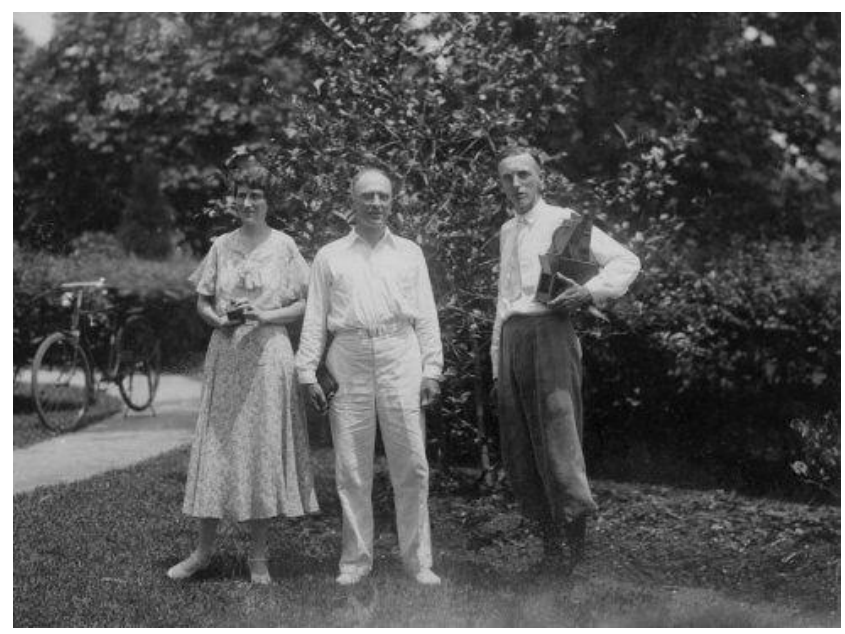

Figure 4. Groff with his wife and a friend.

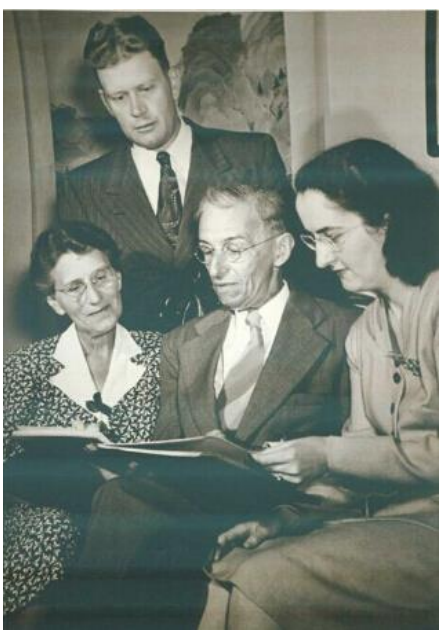

Figure 5. Groff (middle, front) and his wife (left, front).

In 1917, Groff was appointed Dean of the newly-founded Agricultural Department, a complete four-year educational program subordinate to the University of Liberal Arts and Sciences.

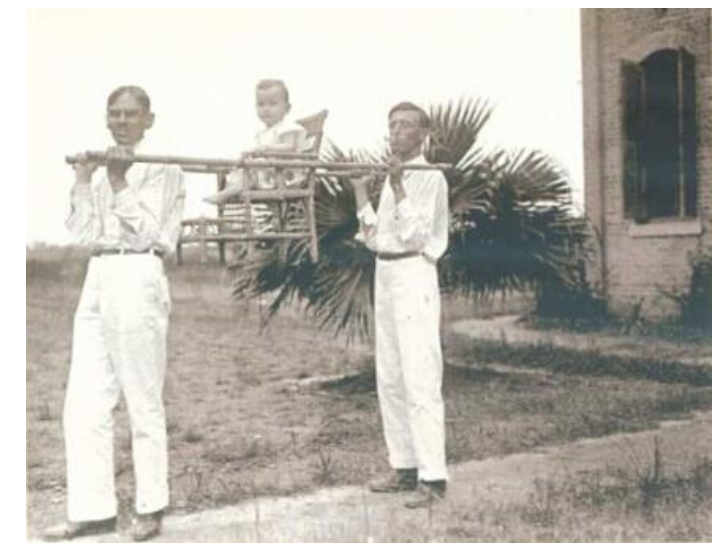

Figure 6. Groff with his son and grandson at Lingnan University.

Most foreign experts who came to Lingnan University brought their families with them, including Prof. Groff - in fact, three generations of Groffs lived at Lingnan. Groff himself, as mentioned above, stayed at the university apart from the years between 1935 and 1937, when he worked for a plant program between the United States and China. 


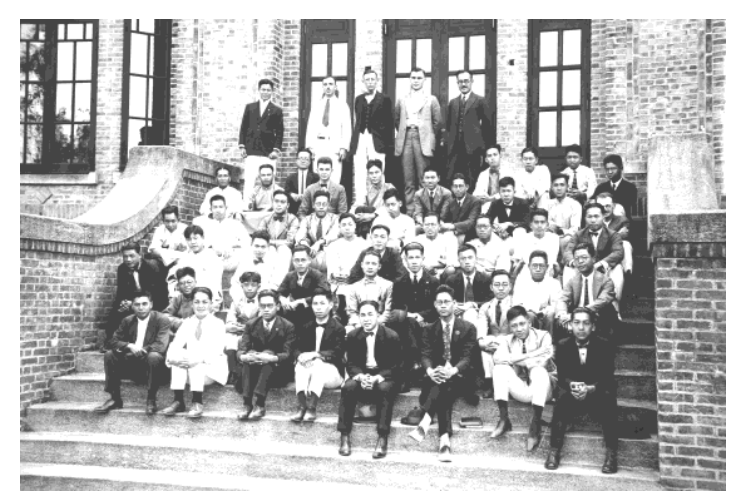

Figure 7. Group photo of teachers and students of Agricultural

Lingnan University of Agricultural Sciences including Prof. Groff (middle back row).

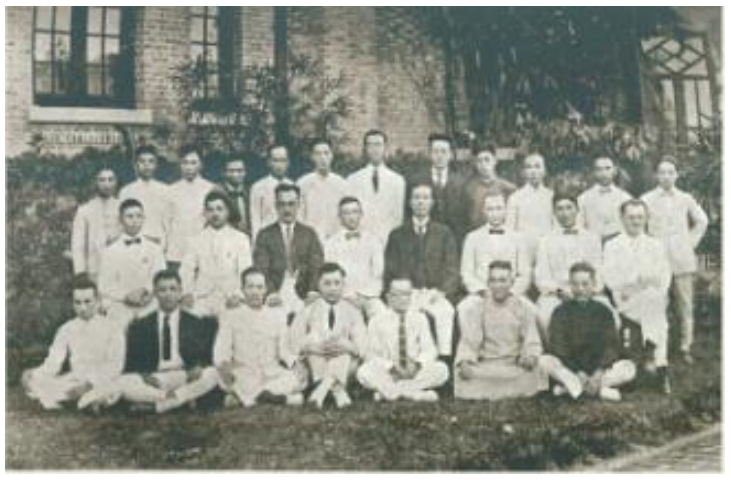

Figure 8. Staff of Lingnan University of

Science, Zhong Rongguang (fifth from the left, second row), Groff (fourth from the left, first row).

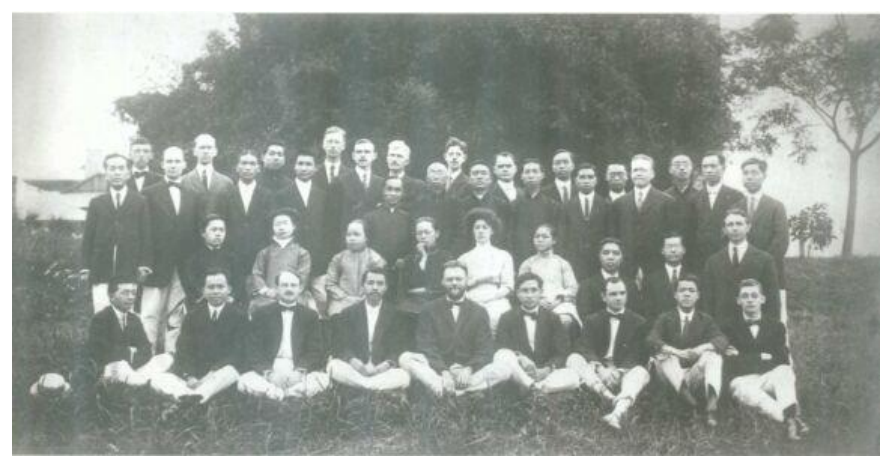

Figure 9. Staff of Lingnan School (1914-1915), including Groff (first from the right, first row).

\section{Groff's Contributions to the Agricultural College of Lingnan University}

Horticulturist Groff's arrival to Lingnan brought a wealth of new planting practices to the campus and sizable advancements in agricultural sciences education for the university students. Some of Groff's most notable contributions included establishing and continuously improving the breeding of Lingnan papaya and the campus afforestation project. Agronomy education was not a part of the university until Groff established the modernized demonstration farm. During his time in charge of the agricultural department, he popularized information regarding agronomy, forestry, horticulture, and food sciences to create an innovative development model that integrated instruction, research, and technology in accordance with the newly developing agriculture plans at the university. His methods - and results - were warmly received by students, other university staff, and the community.

\section{Planning the Most Beautiful Mountain Campus}

The campus covered about 200 acres, with simple coverplate houses and mostly barren hills and farmland, when the university transferred to Kangle village, Guangzhou (now the North Campus of Sun Yat-Sen University.) An American architect was brought on to plan the campus, but even after the first buildings were complete, the school appeared empty and desolate. After his arrival, Groff applied his expertise in horticulture to build and plant Kangle Garden, exacting special focus on the spatial arrangement of the plants to create a modern, geometric layout rife with color and aroma. Kangle was 
designed in accordance with distinctly Chinese styles, as well, down to its inclusion of native crops such as banyan, camphor tree, Cinnamomum burmannii, longan, litchi, Chinese olive, and plantain. More trees were later imported from other countries, including palm, Roystonea regia, leaf thorn, and oil palm, followed by gum tree, cajuput, horsetail beefwood, and hoop pine. In fact, there were thousands of gum trees and cajuputs alone in more than ten varieties. In 1933, the bamboo garden was expanded to include slash pines and loblolly pines. All the tropical plants fit well by design into Guangzhou's climate, and together thrived to offer the university a lush garden with both Chinese and Western elements; the campus was now livelier, more colorful, and hallmarked by a wild profusion of vegetation. Until 1958, trees from the campus accounted for 80 percent of the 1800 species recorded in Flora, a local publication. For the university's famous and largest botanical garden, must go to Groff.

\section{A Pioneer of Modern Guangdong Agriculture}

With Groff in charge of the agricultural department, a modernized demonstration farm was set up, and new plant species and technologies imported for support. Advancements made in the breeding of melon and other fruit, marketing plant seeds, raising animals, and producing dairy goods allowed the university to not only support itself, but to earn enough profits to benefit the surrounding provincial economy.

Promoting the Development of Planting and Breeding Industries. Groff made full use of dozens of the idle fields owned by the Lingnan School outside the city, shaping them into a professional nursery garden and farm land. He assigned tracts of land to students who showed interest in agronomy for them to prepare soil, seed, fertilize, irrigate, and practice field management in planting vegetables with his instruction between classes and coursework. He also enlisted students to experiment with American fertilizer to determine which was best suited to Chinese crops and soil. The pawpaw, called the "King Fruit of Lingnan", was a result of Groff's field work with the originally Hawaiian fruit. Pawpaw, pineapple, orange, vegetable, and seedling gardens - up to 300 types, many of them later successfully marketed - were under the care of Groff and his students.

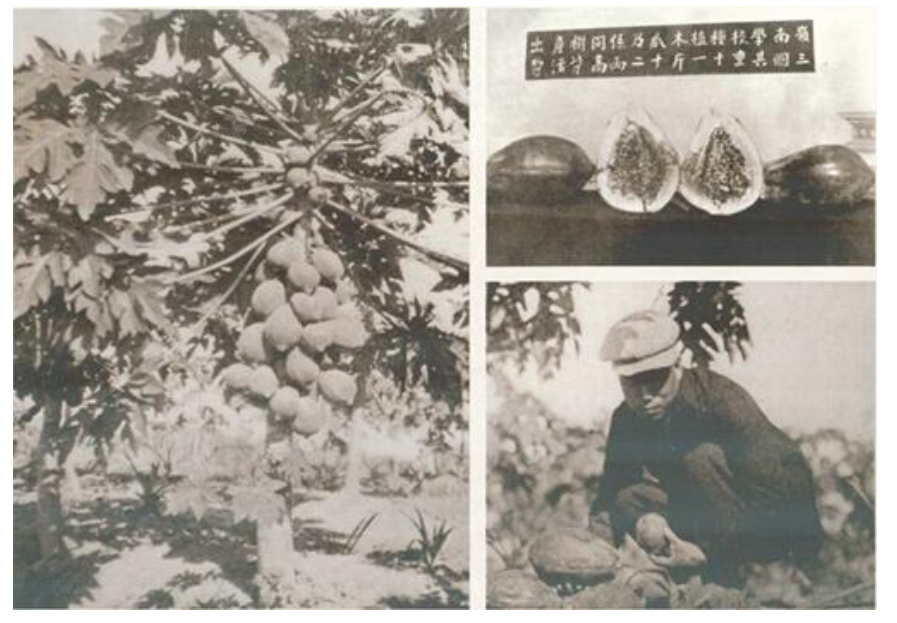

Figure 10. The pawpaw, warmly received by peasants of Guangdong Province, attracted famous officer Marshal Chen Yi, (left) who asked for a taste immediately upon arriving at Sun Yat-sen. 


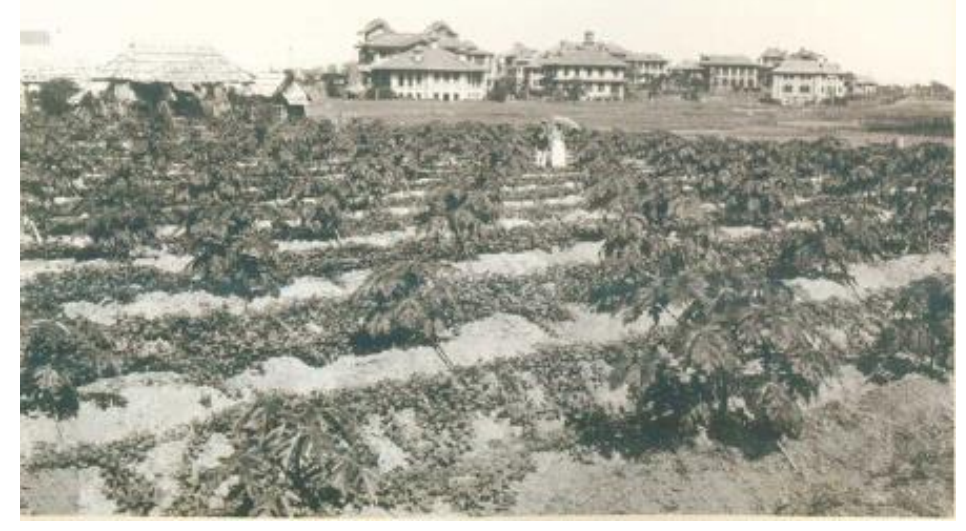

Figure 11. Lingnan pawpaw garden.

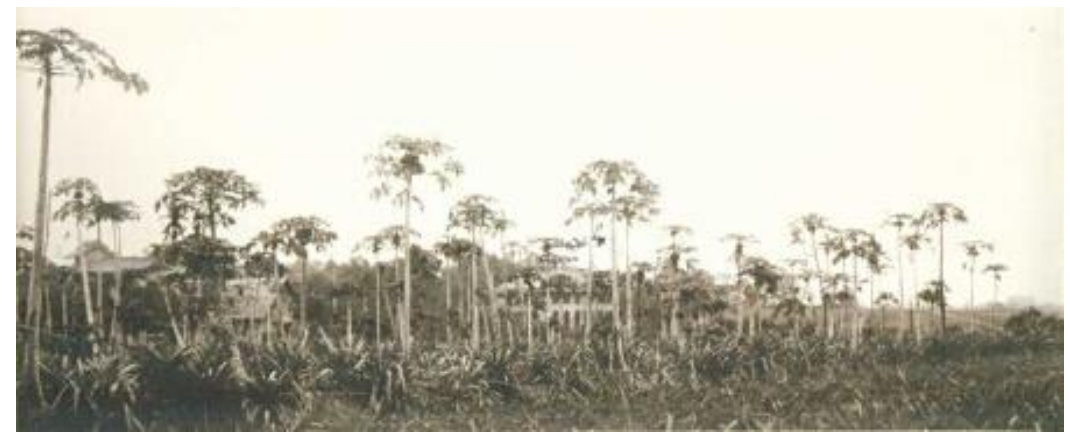

Figure 12. Pineapple and pawpaw plantation.

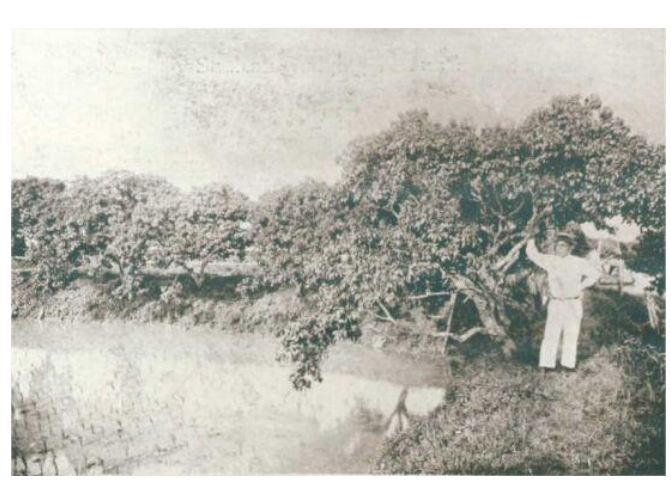

Figure 13. Litchi garden, Agricultural College (150 plants).

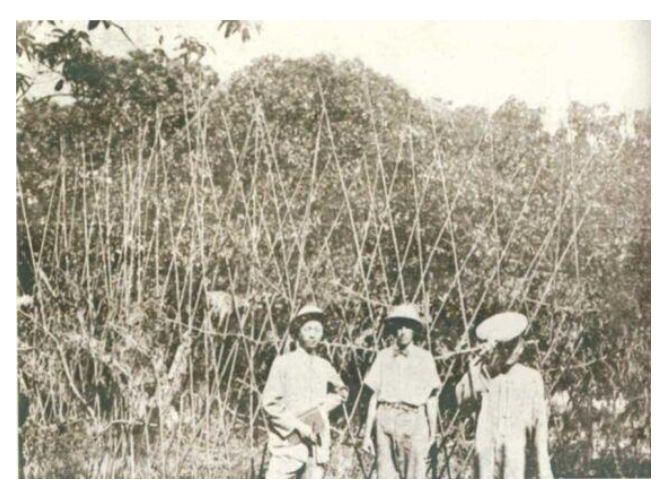

Figure 14. Researching the legendary Gualv Litchi from Zengcheng city; Mr. Guo Huaxiu (left), Professor Groff (middle).

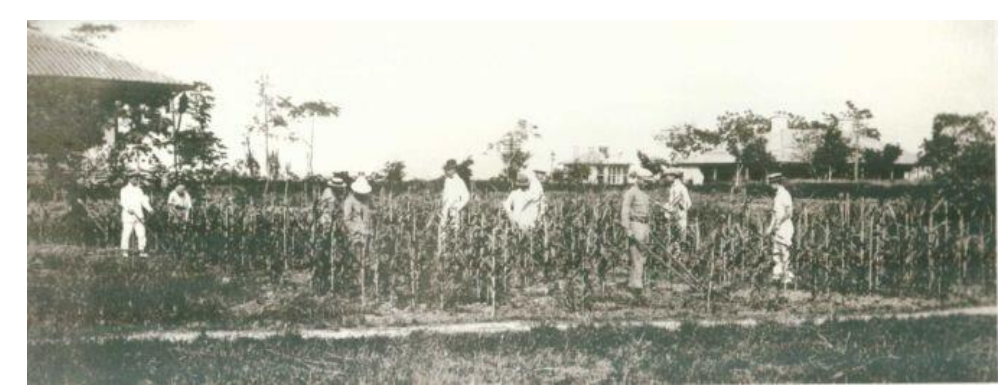

Figure 15.The field investigation of the corn by first-year students in agricultural sciences in 1918 


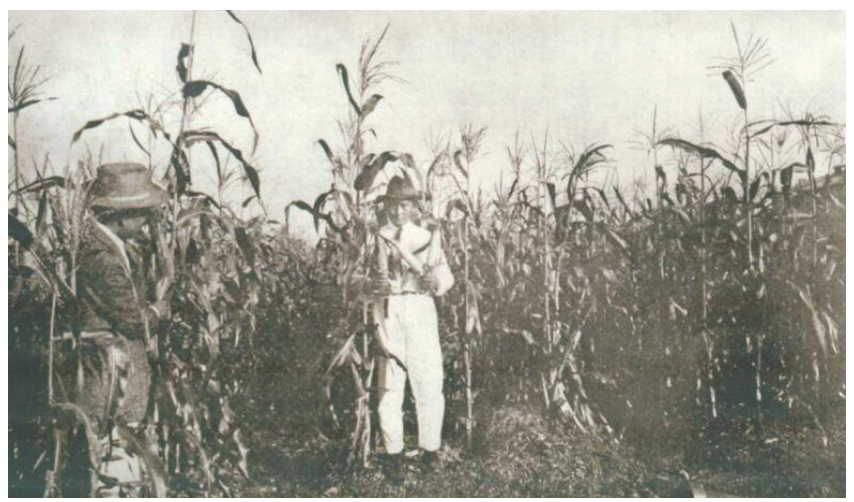

Figure 16. Harvest of American sweet corn, which was done up to four times per year. Several of these breeds are still in use today.

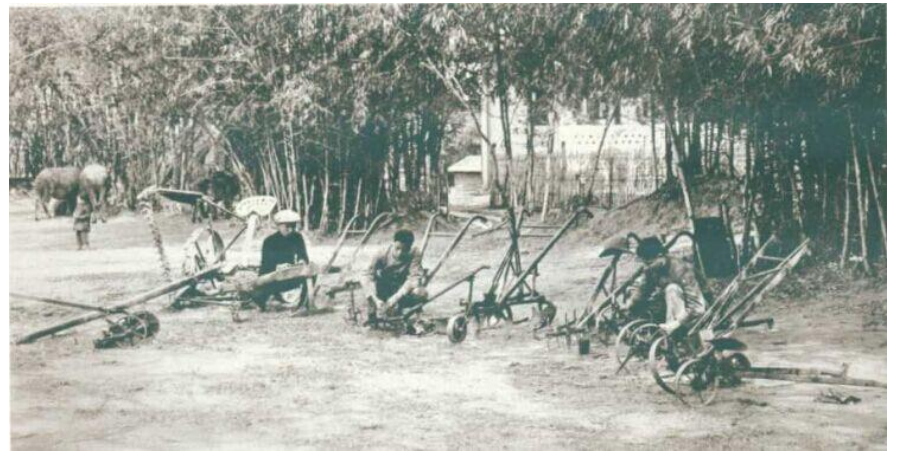

Figure 17. American farm tools on trial by agricultural science students. The farm imported an American field mower, walk-type sower, and walk-type weeder, as well as building an advanced farmhouse that was very unusual at the time. The modernized demonstration farm was quite an eye-catcher and received a large amount of visitors.

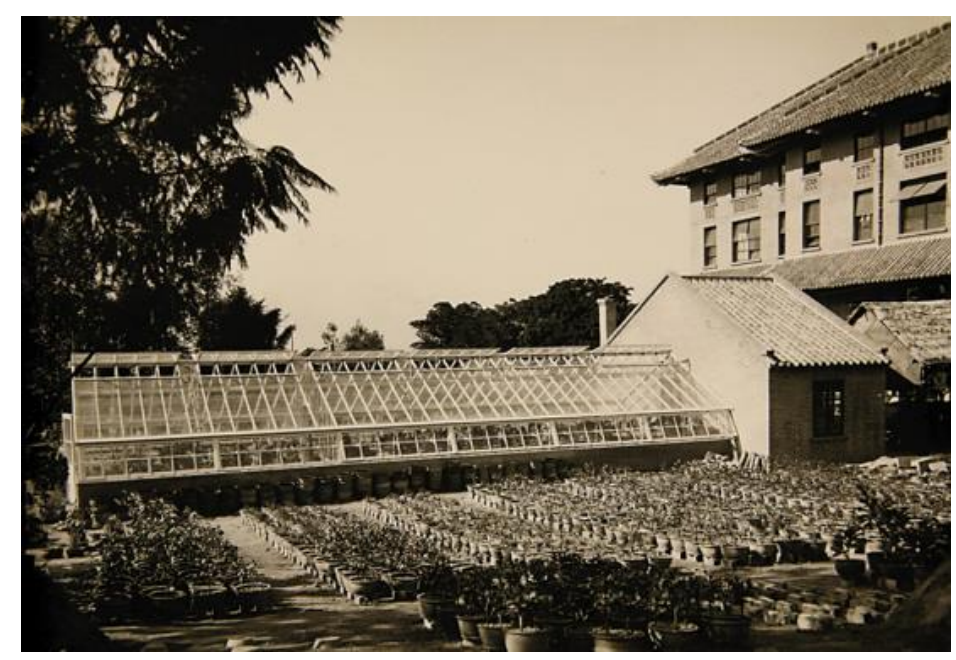

Figure 18. Modern greenhouse built in 1929. 


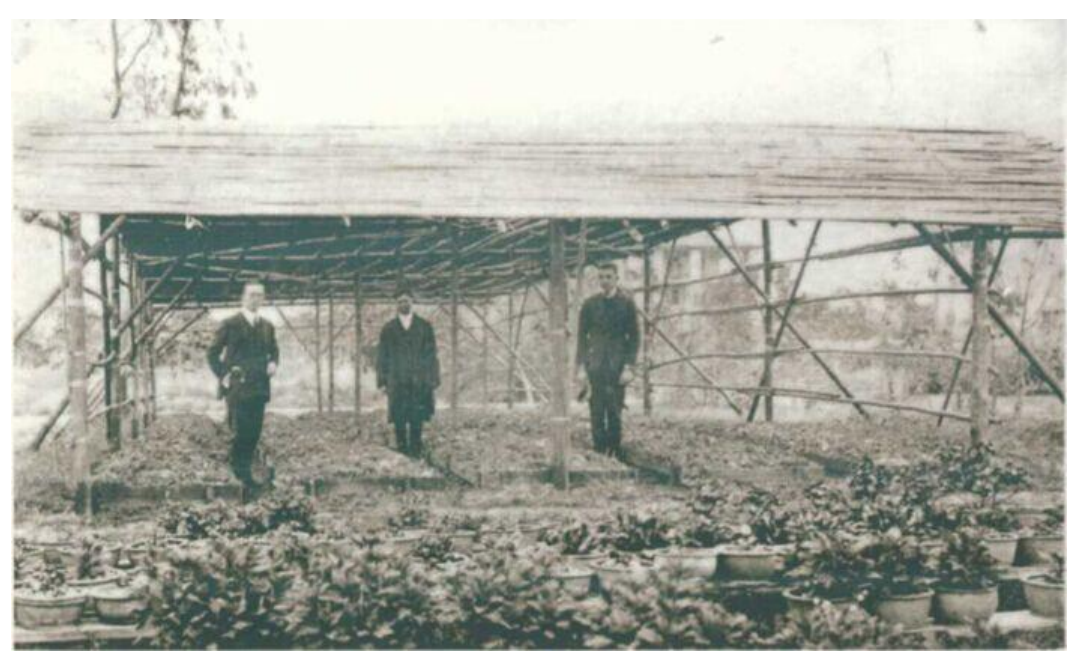

Figure 19. Seeds both domestic and foreign collected and tested prior to transplantation to Lingnan, eventually bringing profit to the university and its surrounding community.

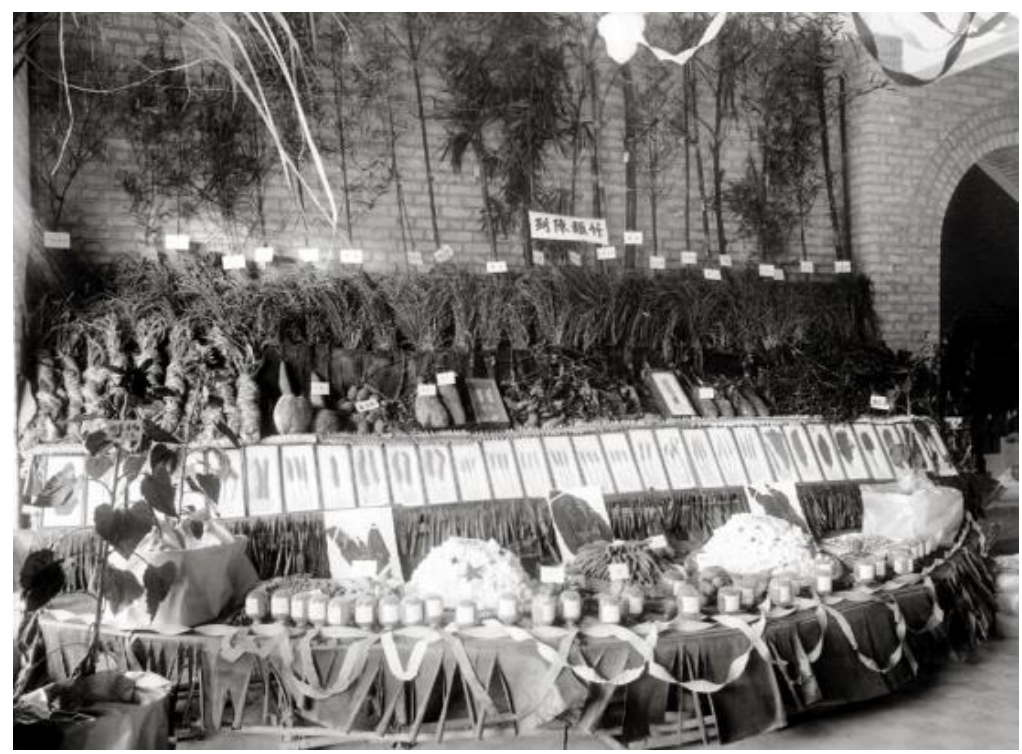

Figure 20. Products cultivated by Agricultural College.

Groff was among the first to introduce new (and profitable,) plants to Lingnan University including peaches, apricots, pears, and navel oranges. Six pomegranate breeds from America and other varieties were planted experimentally - macadamia nut, cinnamon, jackfruit, avocado, cape gooseberry, sweet-waxy maize, and beans from Peru, among others. Groff also helped introduce notable Chinese breeds to the rest of the world, including the Momordica grosvenori, which is native to the tropical and sub-tropical regions in the south of China. Momordica grosvenori was once exclusive to the royal family, not only because of its portended ability to relieve cough, constipation, and glycosuria, but also because it makes an excellent sweetening agent; its extract has sweetness 300 times that of ordinary sugar. It was Groff who discovered and named this fruit while investigating the native vegetation of Guilin, Guangxi Province.

Groff cared so much for the Lingnan University that during a period of sick leave spent in America in 1941, he built a plant-exchange center in Florida, where the climate is similar to that of Guangzhou. Unfortunately, there was no chance for the plants available to be sent to Lingnan University due to the Japanese aggression against China 
of the time.In 1945, after the World War II, Groff returned to China and wrote the book Achievements Made by the Agricultural College of Lingnan University, which covered the previous 35 years of the school's history. Later, he was among the officers who helped revitalize South China, working in the Guangdong Regional Office of the United Nations Relied and Rehabilitation Administration (UNRRA) for 15 months helping to introduce new seeds of agricultural crops.

In summary, Groff brought a great deal of valuable knowledge regarding agronomy, forestry, horticulture, and food sciences to Lingnan University, thus bringing modern agronomy to the school and ushering it onto a global stage.

Promoting the Development of Aquaculture and Food Processing.Foreign experts brought to the university were fond of milk, so the staff raised money to import Holstein and Toggenburg dairy cows so as to ensure a continuous supply. Groff, naturally, was in charge of the import and helped to set up the dairy farm, which had enough dairy cows not only to satisfy the university staff but also to market to the surrounding community - dairy products brought in 180 dollars, in fact, which was a remarkable sum at the time. The farm also functioned to help agronomy students learn new skills and practices. Later, the farm was extended to include about 140 dairy cows from the West, India, and China, plus 25 goats and an additional pig farm and chicken farm, allowing students to butcher pigs, cure, process, and pack meat, and produce cheese.

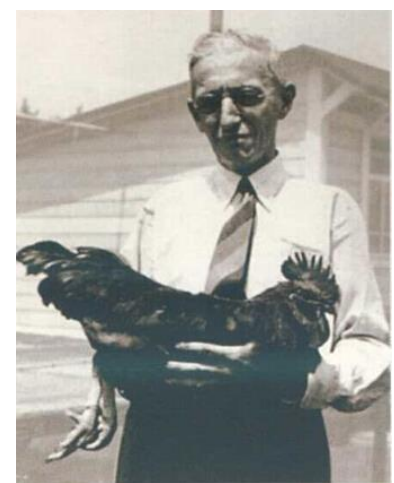

Figure 21. Professor Groff with a chicken from the farm.

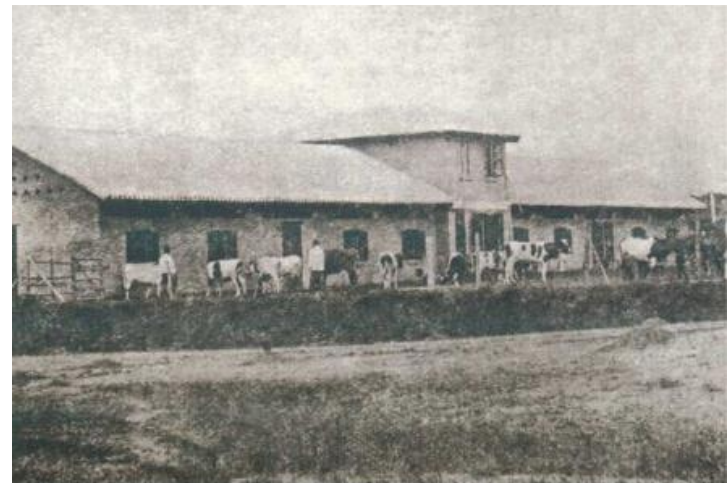

Figure 22. The first home for dairy cattle of Lingnan Farm Produce Processing Company, 1925, where Lingnan milk was produced for the school and surrounding community.

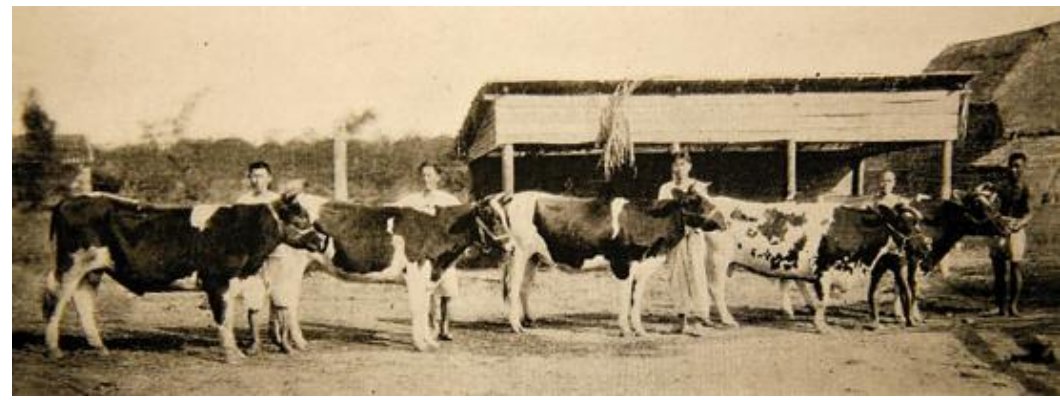

Figure 23. Dairy cows from the West. 


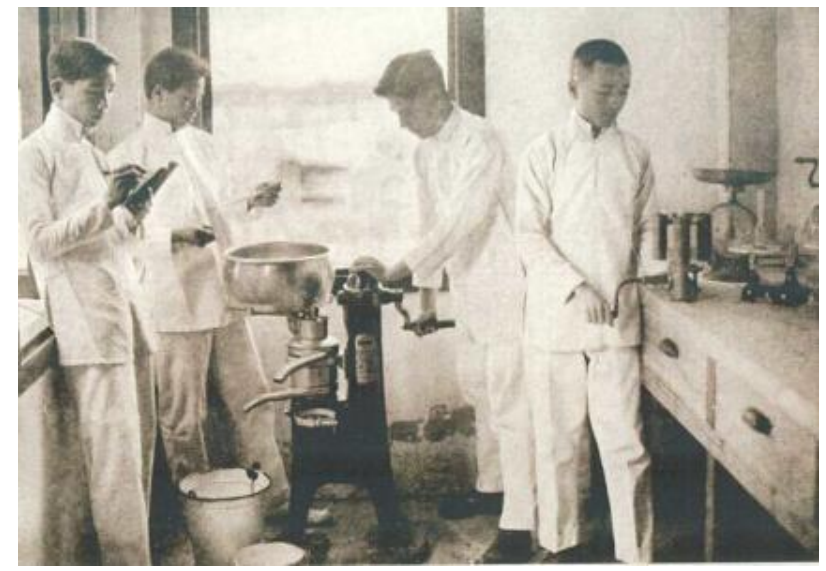

Figure 24. Agricultural Science students making cheese.

Milk from the farm was very popular with staff and students, and as such was often in short supply for those outside the university.

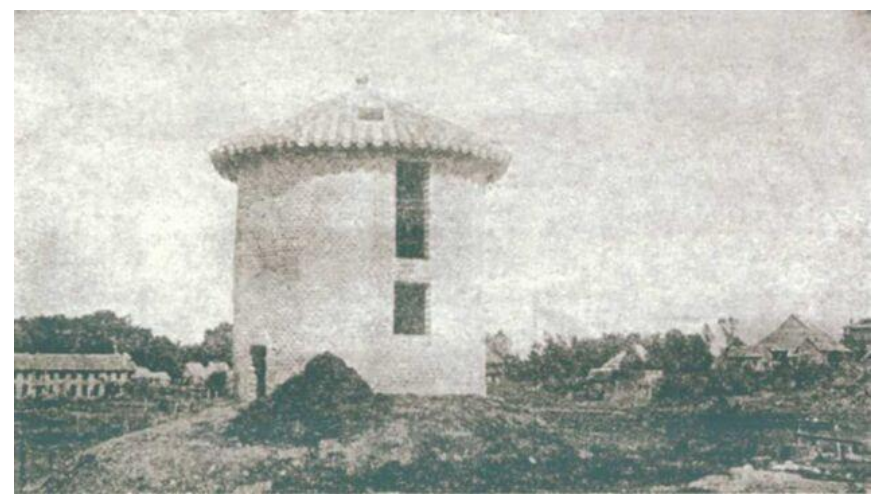

Figure 25. Ensiling Tower, built in 1923 from 50 tons of material.

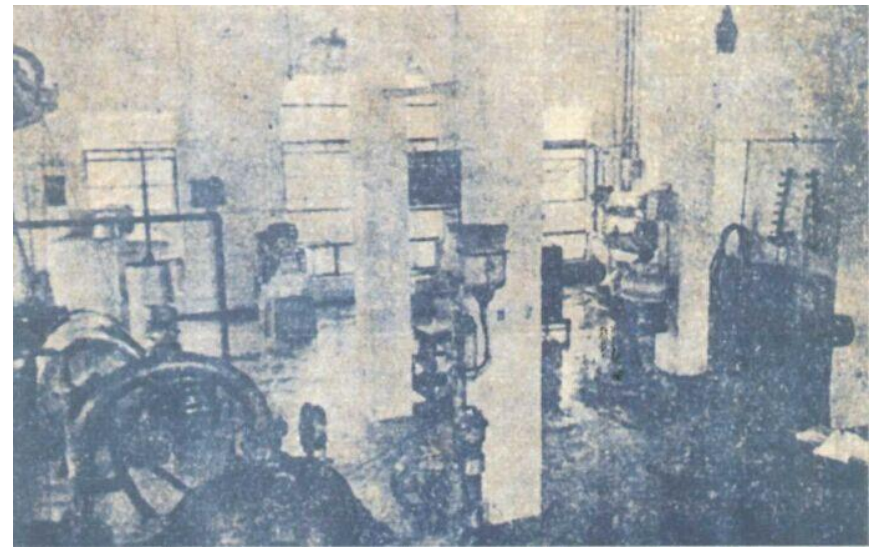

Figure 26. Manufacturing plant where Lingnan Cheese, Lingnan Cream, and Lingnan Ice Cream were produced.

The pasture and dairy manufacturing plant, taken over by Professor Li Yonglu after 1939, made Lingnan Milk and Lingnan Ice Cream famous throughout the surrounding province as well as in Hong Kong and Macao. The dairy project further laid a solid foundation for such disciplines as dairy cow breeding and processing of dairy goods, which were otherwise uncommon in the region at the time. Huanong Yogurt, which originated at Lingnan University, has become a brand deeply rooted in history and highly reputable. 
Promoting the Development of Disciplines and Academic Exchange. In 1921, supported by financial aid from the Guangdong government and such prestigious businessmen as Li Yutang, Ma Yingbiao, and Chen Lianbo, land just west of the school was purchased for RMB 300,000 and a building constructed to house the Lingnan University of Agricultural Sciences (now Ten Friends Hall) with Groff as its President.

In 1927, the agricultural program was incorporated into Lingnan University and reconstructed to become the Agricultural College. Groff served, in order, as dean of the college, director of the Horticulture Department, and head of the Center for Introducing Economic Plants, during which time periodicals such as Lingnan Agronomy Periodical and Farming Periodical (Bimonthly) were issued as a platform to communicate regarding scientific innovations at the university with the rest of Guangdong, (with Groff as the chief editor.)

During his third year in China, Groff conducted extensive research south of the Five Ridges and throughout southern China to study native plant resources. In 1915, Groff, assisted by Meryl of the Science Bureau of the Philippines, established a herbarium to house the specimens collected. Said herbarium became the largest collection of plants native to southern China. Groff also placed special focus on the oranges of Chaozhou-Shantou areas, eventually compiling a valuable report on Guangdong citrus and publishing a paper entitled "Methods of Preventing Insect Attack to Oranges" in the Annual Report of the Lingnan Society of Agronomy. Groff focused further research on litchi and longan, fruits typical of Lingnan and its surrounding areas. He surveyed their varieties and learned about the planting methods by exhaustive work in local fields, traveling even as far as Zengcheng city to study the Gualv litchi.

Groff was the first to study the morphological structure and its mechanism in terms of modern botany. In 1918, he received his Master's Degree of Horticulture from the University of Pennsylvania in part due to his extensive research of the litchi fruit. His paper, Lingnan Litchi, was awarded the top prize by the Ministry of Agriculture and Forestry of the Republic of China in 1919. In 1921, his book, Longan and Litchi was published in New York and was among the first to introduce longan and litchi fruits to the Western world. The book has been reprinted many times since its initial publication, even as recently as 2008. In fact, Groff was interested in litchi for about 20 years - in 1943, he published documents including Biological factors of Successfully Planting Litchi, and Reinterpretation of Litchi History of Chenzi of Fujian Province in the Florida Bulletin of Horticulture. Groff also helped in other ways to bring the litchi fruit to America. In 1918, he brought back with him some litchi seedlings (including nuomici, laurel, and black leaf,) on vacation and the varieties took off - the Hawaiian government even named one of their litchi seedlings, which were propagated by grafting, after him.

Litchi was not Groff's sole focus, however. In 1937, when Groff led a delegation of international geographers in a field investigatation of Guangxi, he discovered the now famous Momordica grosvenori and brought it back to Lingnan. Later, Groff and botanist Swiff made a detailed study of the fruit and published Momordica Grosvenori in Guangxi, which filled in previous gaps of knowledge regarding the fruit and instantly popularized it throughout the region and abroad. 


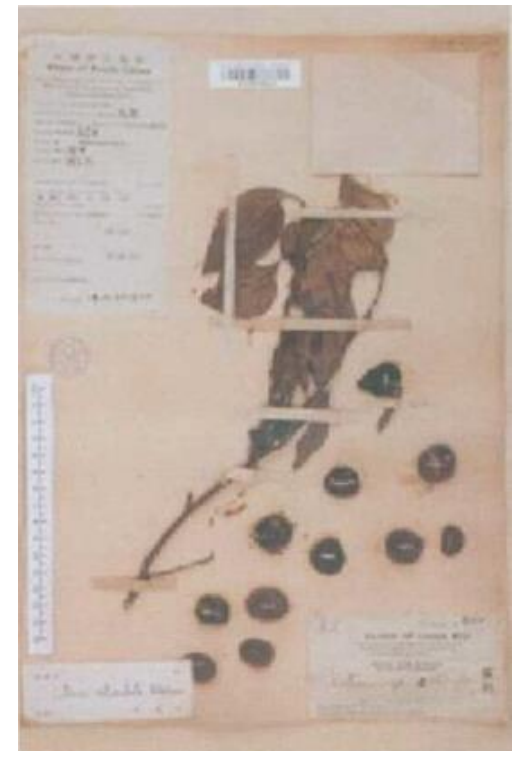

Figure 27. Herbarium Collected by Professor Groff in Chaoan County December, 1918.

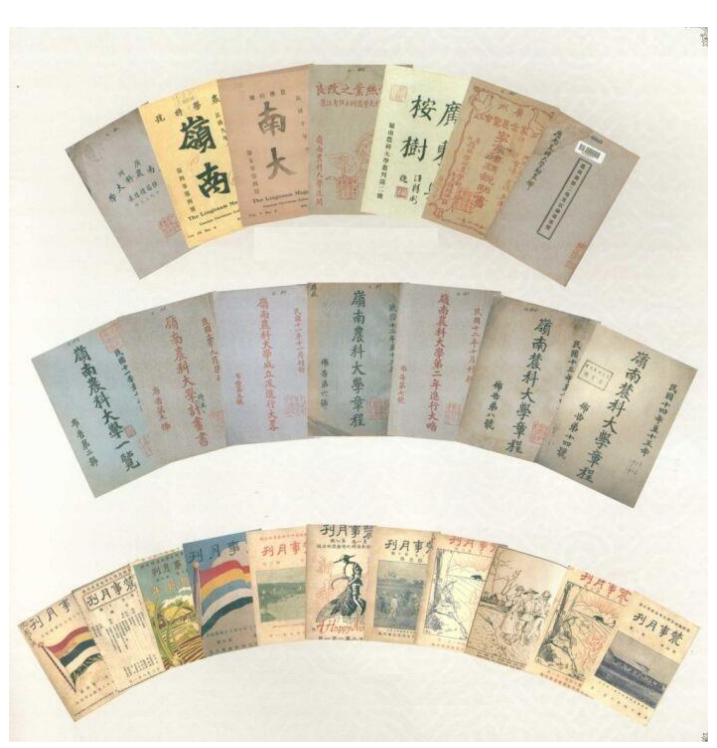

Figure 28. Periodicals by Lingnan University of Agricultural Sciences.

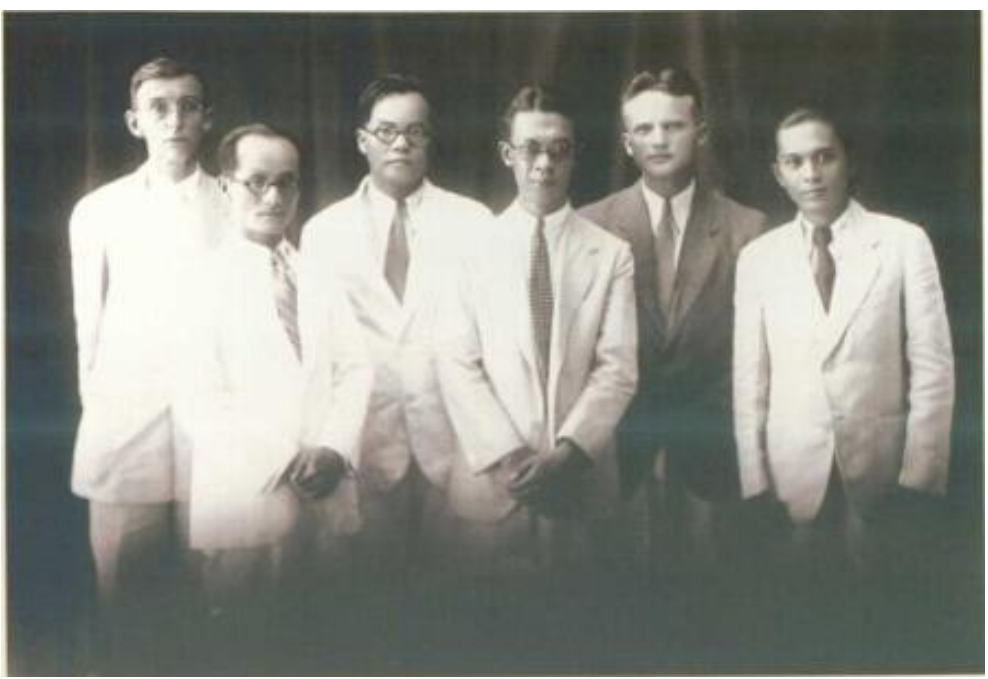

Figure 29. Teachers in Guangzhou, China, from Pennsylvania University in 1931.

Lingnan University reached agreements, officially or unofficially, with over ten universities such as Harvard, Yale, Columbia, Hopkins, Cornell, Oberlin, Stanford, and Washington State University to include graduates in continuing studies in agriculture and horticulture. Many of the graduates who went on to complete postgraduate studies abroad eventually returned to Lingnan University and made excellent teachers. 


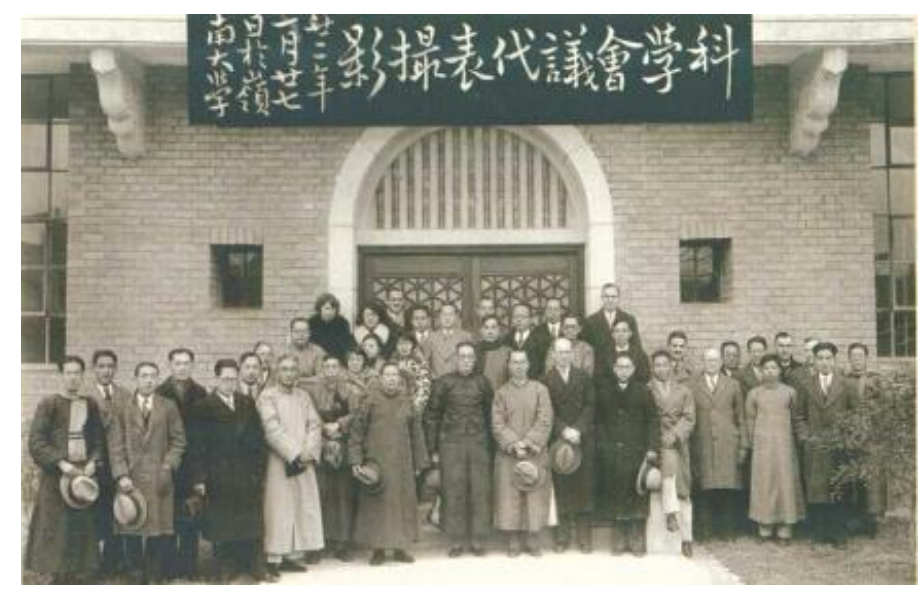

Figure 30. Group photo of attendees of Science Seminar of Lingnan University, 1933; Deng Zhiyi (fourth, left), Groff (sixth, left).

Groff is worth writing about not only in praise of the numerous and lasting concrete contributions to Sun Yat-sen University, but because he was a mentor and a friend to China and showed quite moving love and care for China, the Chinese, and Chinese culture. Guo Huaxiu, one of the teachers at Lingnan Univesity, conducted agricultural research under Groff's instruction; Groff went on to publish a special report to commemorate him, A Brief Biography of Mr. Guo Hиахiu after Guo died at a young age.In 1947, Groff set out to write a plant handbook after retiring to Laurel, Florida, intended to monograph to record plant resources and facilitate future international plant exchange. Unfortunately, the handbook was yet incomplete at the time of his death. In 1940, Groff was awarded a top prize from the Republic of China to honor his work and achievements over his 30 years at Lingnan University for 30 years. In 1953 he and another four individuals were granted the First Excellent Alumnus award by Pennsylvania State University. Groff passed away at the age of 70 on December 4, 1954, leaving behind about 50 writings and a lasting legacy as an educator and horticulturist.

\section{Postscript}

In the period of the Republic of China, agricultural colleges of the University of Nanking and of Lingnan University were among the most prestigious, introducing advanced American systems of teaching, research, and practice to China and making sizable contributions to higher education. China's agriculture, development of the labor force, technical and scientific practices, and the construction of all-around villages benefited from these universities' contributions. Although Lingnan University was incorporated into the Agricultural College of South China in the Department Reconstruction of 1952, many professors and specialists, led by Li Peiwen (the former vice-president) continued to spare no efforts to continually improving the teaching, research, and management of the college (renamed South China Agricultural University in 1984.) In 1979, at the very beginning of the Chinese Economic Reform period, Pennsylvania State University sought cooperation with the Agricultural College of South China. In 1980, two agreements were officially signed between Pennsylvania State University and South China Agricultural University: the Cooperative Planning Protocol and the Cooperative Research Memorandum of Agreement. On May 30, 2007, the two universities, as Sister Seat of Learning, together celebrated their 100th anniversary. With this friendship, the university benefits from the ability to receive loans from the Food and Agricultural Organization and the World Bank to purchase 
necessary devices and send their students and academic visitors abroad. The International Training Center for Silkworm Breeding and Mulberry Growing, two innovative and highly valued parts of the university system, have been a result of this friendship as well. The university has grown throughout its lengthy and esteemed history into a world leader in foreign exchange, and a famous institution of higher learning both at home and abroad.

\section{References}

[1] Huang Juy-an, Modern Education in Guangdong and Lingnan University, 1995 The Commercial Press, "In Chinese".

[2] a hundred years Historical Photos of South China Agricultural University 1909-2009,2009, the South China Agricultural University Centennial Series "editorial board, the Guangdong People's Publishing Press, "In Chinese".

[3] Ni Chuan, An American and Lingnan papaya, the Yangcheng Evening News January 22, 2011, "In Chinese".

[4] Ceng Fan-ye, The history of Agricultural University of Lingnan University _1908_1952 _ investigation, "In Chinese".

[5] Lingnan University - History and development, "In Chinese"

http://ln.edu.hk/cht/info-about/history 